\title{
Zanette T. Glørstad and Kjetil Loftsgarden (eds.): Viking-Age Transformations: Trade, Craft and Resources in Western Scandinavia
}

\author{
Routledge, Abingdon/New York \\ 2017, 289 pages, ISBN 978-1-4724-7077-5
}

Viking-Age Transformations contains thirteen papers (with eighteen authors) arising from a conference on 'The Power of the Market' organised by the Centre for Viking-Age Studies (ViS) at the Museum of Cultural History, University of Oslo (under the leadership of Professor Dagfinn Skre), in December 2013, with support from the Department of Archaeology, Conservation and History (IAKH), University of Oslo, and the Department of Archaeology, History, Cultural Studies and Religion (AHKR), University of Bergen.

In their preface to this 'anthology', the co-editors - Zanette Glørstad (Oslo) and Kjetil Loftsgarden (Bergen) - indicate that the selected papers 'cover developments roughly within the geographic area of present-day Norway [...] pertaining to the transformations of the Viking-Age economy and its social ramifications' (page vii), while admitting that 'the contributions address disparate topics' (page vii). In fact, there is no full coverage of 'present-day Norway', given that such does not equate with 'western Scandinavia', with references to northern Norway being far and few between. On the other hand, some papers extend the chronological range of the volume well into the High Middle Ages (1150-1350).

The disparate nature of the topics under consideration clearly presented the editors with a problem of organisation, and they opted for a scheme in which twelve of the papers are grouped equally into three 'Parts', entitled 'Trade and traders', 'Production and resources' and 'Sites of trade'. In practice, this is not an entirely satisfactory arrangement, so it is not altogether surprising that they are otherwise reviewed by Dagfinn Skre in his introductory chapter, entitled 'Viking-Age economic transformations: the West-Scandinavian case', which provides (in the editors' words, page viii) 'an overview of the Stand der Forschung in terms of trade, production and consumption in the period, as well as connecting them to the main economic transformations in western Scandinavia, and examines the pertinent theoretical considerations embedded in the analysis of these economic processes'. Although Skre does reference all the other contributions in his invaluable paper, they are not taken 
comprehensively into account so as to allow him to concentrate on four 'particularly prominent' economic transformations: production of marketable goods; long-distance trade; urbanisation and markets; and monetisation. In fact, the latter topic receives only minor consideration in this volume, but then Skre had two relevant papers in preparation (see now Skre 2017a; 2017b).

'Pertinent theoretical considerations' introduce Part I, being the subject of the paper by Eivind Heldaas Seland, 'Approaching trade in pre-state and early state societies', although without direct reference to the Viking Age. The other three papers that constitute 'Trade and traders' are organised chronologically, beginning with Olof Holm's detailed study of 'The use of silver as a medium of exchange in Jämtland, c. 875-1050', in which he analyses grave finds of weights and scales (and some hack-silver) from Jämtland (Sweden), concluding that from the mid-tenth century the farmers there were operating as independent traders, even if the whereabouts of the primary use of their trading equipment inevitably remains unknown.

The next paper is the most substantial in the volume, that by Gitte Hansen on 'Domestic and exotic materials in early medieval Norwegian towns: an archaeological perspective on production, procurement and consumption', demonstrating that 'in contrast to their VikingAge counterparts, early medieval Norwegian towns were primarily consumers, not producers' (page 81) and that they 'also served as nodes in international, interregional or regional networks of exchange' (page 82). This is the first such overview of this subject (assembling finds from thirteen of medieval Norway's fourteen known towns) and more could not have been expected, but textiles (other than the sewing thread and silk embroidery yarn utilised in shoemaking) might have been considered worth mentioning, and the only reference to coinage is the curious statement that 'from 1050-1100 minting was possibly carried out' in Trondheim (page 69). But Hansen is to be congratulated on the compilation of a major new resource - and for identifying new research questions in the process.

Part I concludes with a venture into the High Middle Ages with a paper by Frode Iversen and Svein H. Gullbekk on 'The price of justice and administration of coinage'. This investigates the cost of arranging Norwegian lawthings in the thirteenth century (which may have amounted to as much as c. $100 \mathrm{~kg}$ of silver a year) and the manner in which the king and the state used the thing to administrate the monetary system (by the practice of periodic recoinage).

Three of the papers in Part II are subject surveys, beginning with Ole Tveiten and Kjetil Loftsgarden on 'The extensive iron production in Norway in the tenth to thirteenth century: a regional perspective', documenting and discussing its 'massive rise ... on a regional as well as a national level' (page 121), during the period under consideration. In 'Soapstone vessels and quernstones as commodities in the Viking Age and Middle Ages', Irene Baug concentrates on trading networks rather than production. In the third survey, Kathrine Stene and Vivian Wangen consider 'The Uplands: the deepest of forests and the highest of mountains - resource exploitation and landscape management in the Viking Age and early Middle Ages in southern Norway'. The other paper in 'Production and resources', by Unn Pedersen on 'Viking-period non-ferrous metalworking and urban commodity production', is concerned specifically with archaeological evidence from the early Viking town of Kaupang, where urban activity ceased c. 930, in which she demonstrates the Viking-Age development of serial production, even if production on commission was maintained in parallel. 
Part III, on 'Sites of trade', opens with a paper by Zanette T. Glørstad and Camilla Cecilie Wenn who provide 'A view from the valley: Langeid in Setesdal, South Norway - a VikingAge trade station along a mercantile highway'. This is, however, best taken together with that by Holm (in Part I) for it demonstrates that the tenth- to eleventh-century cemetery at Langeid likewise contained the 'graves of members of a community actively engaged in regional exchange networks, connected to larger networks of exchange' (page 201), although there is as yet no direct evidence for the existence there of the 'trade station' of their title. This contrasts with the newly-excavated evidence presented in a preliminary report by Jan Bill and Christian Løchsen Rødsrud, on 'Heimdalsjordet: trade, production and communication', for an important (if undocumented) Viking-Age seasonal trade and production site located beside a natural harbour in the immediate vicinity of the famous Gokstad ship burial.

Part III continues with a paper by Kjetil Loftsgarden, Morten Ramstad and Frans-Arne Stylegar, on 'The skeid and other assemblies in the Norwegian "Mountain Land", in which they consider the multi-functional use of these small-scale seasonal meeting places, and it concludes with a historical account by Frode Iversen of 'The urban hinterland: interaction and law-areas in Viking and medieval Norway'.

The book's substantial index is a welcome asset for such a collection; indeed, it is an essential feature for making the most of its contents, although it also serves to highlight topics that might be considered to have been somewhat neglected, such as 'mints and minting' and 'textiles' (both with only three entries), or even overlooked altogether, e.g. 'salt' and 'touchstones' (for the importance of the latter, see now Ježek 2017).

Overall, this is a most welcome volume, combining useful summaries of research newly completed, or still in progress, with concise surveys of a range of topics from the Viking Age to the High Middle Ages. It is of no particular concern that not every paper engages directly with Viking-Age transformations, for all contribute to the wider issue of the economic transformation of West Scandinavia during the eighth to thirteenth centuries - and thus to a book yet to be written, but much needed, on 'Viking-Age Transformations in Norway'. Meanwhile, ViS conferences have continued to take place in Oslo, and further volumes of 'adapted' papers are in the process of publication. However, should the editors of these subsequent ViS volumes consider re-using 'Table 0.1 An overview of the overarching time designations used in European history c. 550-1500, compared with the corresponding general period designations used in Sweden and Norway' (page ix), they would do well to think about introducing some revisions. In the second column, headed 'Norway and Sweden', the 'Viking Age' is dated by the editors to c. 800-1050, although elsewhere Skre prefers us to think in terms of what might be called a 'long Viking Age', from c. 750-1100, and they divide it into 'Early' and 'Late', despite the Swedish (Holm's) use of its, likewise well-established, tripartite division into the early, middle and late Viking periods (cf. Graham-Campbell 1980:5-7). There is, however, greater over-simplification in the first column, headed 'Continent \& UK'; in my discussion of 'Medieval chronologies' in the introduction to the first volume of The Archaeology of Medieval Europe (Graham-Campbell with Valor (eds.) 2007:17-18), I highlighted how the British terminology for the periodisation of the Middle Ages (in archaeology) contrasts with that employed in Germany where, to complicate matters further, archaeology and history use differing systems. 


\section{Literature}

Graham-Campbell, James

1980 Viking Artefacts. A Select Catalogue. British Museum Publications, London.

Graham-Campbell, James with Magdalena Valor (eds.)

2007 The Archaeology of Medieval Europe, vol. 1. Eighth to Twelfth Centuries AD. Aarhus University Press, Aarhus.

Ježek, Martin

2017 Archaeology of Touchstones. An Introduction based on Finds from Birka, Sweden. Sidestone Press, Leiden.

Skre, Dagfinn

2017a Monetary practices in early medieval western Scandinavia (5th-10th centuries AD). Medieval Archaeology 61(2):277-299.

2017b Scandinavian monetisation in the first millennium AD - practices and institutions. In Encounters, Excavations and Argosies. Essays for Richard Hodges, edited by John Mitchell, John Moreland, and Bea Leal, pp. 291-299. Archaeopress, Oxford. 